JeMAS 15(1) (2019) 89-97
Jttp://journal.unnes.ac.id/nju/index.php/kemas

\title{
Unified Theory of Acceptance and Usage of Technology (UTAUT) Model to Predict Health Information System Adoption
}

\author{
Siti Nurhayati ${ }^{\circledR}$, Dian Anandari ${ }^{1}$, Wahyu Ekowati ${ }^{2}$ \\ ${ }^{1}$ Public Health Department, Faculty of Health Sciences, Jenderal Soedirman University \\ ${ }^{2}$ Nursing Department, Faculty of Health Sciences, Jenderal Soedirman University
}

\begin{tabular}{l} 
Article Info \\
\hline Article History: \\
Submitted December 2017 \\
Accepted March 2019 \\
Published July 2019 \\
\hline Keywords: \\
UTAUT Model, Adoption \\
DOI \\
https://doi.org/10.15294/ \\
kemas.v15i1.12376
\end{tabular}

\begin{abstract}
In order to improve the quality and performance of health services, health information systems are one of the most important technologies in health management. This study aims to determine the factors that influence the adoption of nutrition information system by nutrition officers of primary health care by using Unified Theory of Acceptance and Usage of Technology (UTAUT) Model. This research is quantitative research with survey approach, located in 39 primary health care of Banyumas district. Sampling technique using purposive sampling. Respondents are 50 people. The research instrument used questionnaire. Based on regression test results known that factors related to use behaviour is behavioral intention. While the facilitating condition is not related to use behavior. Factors associated with behavioral intention is the performance expectancy, effort expectancy and social influence.
\end{abstract}

\section{Introduction}

Quality improvement and cost reduction are the two main challenges in health services. In order to improve efficiency and effectiveness, the application of information technology and computers in health services developed significantly (Blumenthal and Glaser, 2007; Chaudhry et al., 2006; Jha et al. 2009). Some studies have found that if health services do not adopt information technology for additional support, management will become ineffective, and lose credibility by patients (Aggelidis and Chatzoglou, 2009). Therefore, information technology needs to be applied to health services.

Information and communication technology (ICT) is all digital technology that supports the retrieval, storage, processing and exchange of electronic information for health promotion, preventing disease, diagnosing diseases, managing chronic diseases, and so on (Bashshur et al., 2009; Gagnon et al. 2012). In the health sector, ICT refers to a series of projects or services that enable telehealth, interdisciplinary clinical support, and knowledge transfer (Gagnon et al, 2013). The use of ICTs has the potential to promote health services centered on lower-cost patients, improve the quality of services and share information, educate health professionals and patients, encourage new forms of relationships between patients and health care providers, 
reduce travel time, etc. (Bashshur et al, 2009; While and Dewsbury, 2011). The use of ICTs in the health care system has promoted the quality of health and access to health services which has led to significant reductions in errors and medical costs. Internet-based health applications include electronic health records, electronic prescriptions, e-health, to improve the efficiency of health services and reduce errors in the process of providing care.

The application of information technology in health systems often faces problems, complexity and health information systems adopted by healthcare providers slowly (Lluch, 2011). Health institutions in adopting the application and technology of health information systems focus more on the sophistication of functional features and techniques than the needs and features of end users (Jha et al., 2006). As a result, the level of use of health information technology (IT) is low, resistance, abandonment of the use of health information technology (IT), and the demand for alternative methods. Therefore, to get a substantial effect, reactions from end users must be considered thoroughly (Holden and Karsh, 2010).

Although the benefits of information technology for health services already known, but still needed a new adaptation for health workers. Implementation of information technology in health care systems has been proven difficult (Boonstra and Broekhuis, 2010; Davidson and Heslinga 2006). The application of information technology in health systems often faces problems, complexity and health information systems adopted by healthcare providers slowly (Lluch, 2011). Health institutions in adopting the application and technology of health information systems focus more on the sophistication of functional features and techniques than the needs and features for end users (Jha et al., 2006). As a result, the usage level of health information technology (IT) is low, resistance, abandonment of health information technology (IT) usage, and the demand for alternative methods. Therefore, to get a substantial effect, reactions from end users must be considered thoroughly (Holden and Karsh, 2010).

Actually, user acceptance of information technology plays a key role in adopting and implementing new technologies in the health sector. But it is not sufficient in understanding how and how institutions adopt information technology so that it can cause failure in the implementation of new technology (Kijsanayotin et al., 2009). Measurement of adoption rates is very helpful in the success of the implementation of the system, and the use of information technology adoption theory is very important to predict the reaction of end-users to health information technology (Holden and Karsh, 2010). Theories that discuss the issue of adoption of information technology in the social system that developed in the last decade include: Theory Acceptance Model (TAM), and Unified Theory of Acceptance and Usage of Technology (UTAUT) (Liu et al, 2005).

Unified Theory of Acceptance and Usage of Technology (UTAUT) (Venkatesh et al., 2003) is a model developed by combining various models of human behavior theory, namely the Theory of Reasoned Action / TRA, TAM, Motivational Model / MM, Theory of Planned Behavior / TPB, TAM + TPB, Model of PC Utilization / MPCU, Innovation Diffusion Theory / IDT, and Social Cognitive Theory / SCT . Studies that analyze the goal of end users is to actively use health information technology. The UTAUT model is known to have $20 \%$ to $30 \%$ explanatory power greater than TAM, the average only shows an explanation power of 40 to $50 \%$ about end user behavior intentions to use information technology. UTAUT is the most dominant and comprehensive theory in the literature related to current interest in using technology (Schaupp, Carter, and Mcbride, 2010). UTAUT can explain up to $70 \%$ of the variants of the behavior intention. UTAUT is also proven to be robust when used in crosslanguage and cultural studies (Oshlyansky, Cairns, and Thimbleby, 2007). The UTAUT model is a useful tool to assess the chance of success introducing new technology and exploring factors that influence user behavior intentions. This is also possible evaluating interventions, which aim to increase the tendency of users to adopt and use new information systems in the context of UTAUT (Chien et al., 2013)

In recent years, a lot of research have 
been done in the context of adoption and use of information technology in health services to find out acceptance of information technology users and influential factors, important when information technology is implemented in health practices, because of the rapid implementation of information technology in all sub-systems of health. One example is the information system built by the Indonesian Ministry of Health, Directorate of Nutrition.

In order to implement the vision and mission strategy of the Indonesian Ministry of Health, especially the strategy to improve the surveillance system, monitoring and health information, the Directorate of Nutrition has sought to improve the nutrition surveillance system through the consolidation of websitebased nutritional data reporting. NUTRITION INFORMATION SYSTEM is a simple websitebased reporting application and SMS gateway. With this reporting, information about under-five malnourished children can be sent and handled quickly. Information from the application is very helpful for decision makers to be able to coordinate with the region, improve the performance of program implementers and as an evaluation and planner of activities (Kemenkes RI, 2013).

Surveillance through this application has been carried out since 2011, but has never been evaluated. Evaluation is needed to detect the emergence of problems that can disrupt the process of service, management and decision making in health facilities. These problems can come from hardware, software, brainware and sociotechnical components. Evaluation is needed to find out whether the information system is suitable for use, needs to be repaired, or updated. This research aims to determine the factors that influence the adoption of nutritional information systems by puskesmas nutrition officers using the Unified Theory of Acceptance and Usage of Technology (UTAUT) model.

\section{Method}

This is a quantitative research with a survey approach, located in all (39) puskesmas in the work area of the Banyumas DKK that implements the Nutrition Information System. The sampling technique used in this study purposive sampling. The respondents of this study were 50 people, namely puskesmas officers who used the Nutrition Information System. The research instrument was a questionnaire with a Likert scale (strongly agree, agree, disagree, strongly disagree). All questions were valid $(\mathrm{p}<0.05)$ and reliable (Cronbach Alpha> 0.7). Data analysis using linear regression analysis. Figure 1. is a framework for the Unified Theory of Acceptance and Usage of Technology (UTAUT) model.

\section{Result And Discussion}

Based on univariate analysis it was found that the majority of respondents' sexes were women (96\%); the majority of the respondents' ages ranged from $\leq 30$ years $(44 \%)$; the majority of respondents work 6-10 years (30\%); the majority of education respondents graduated

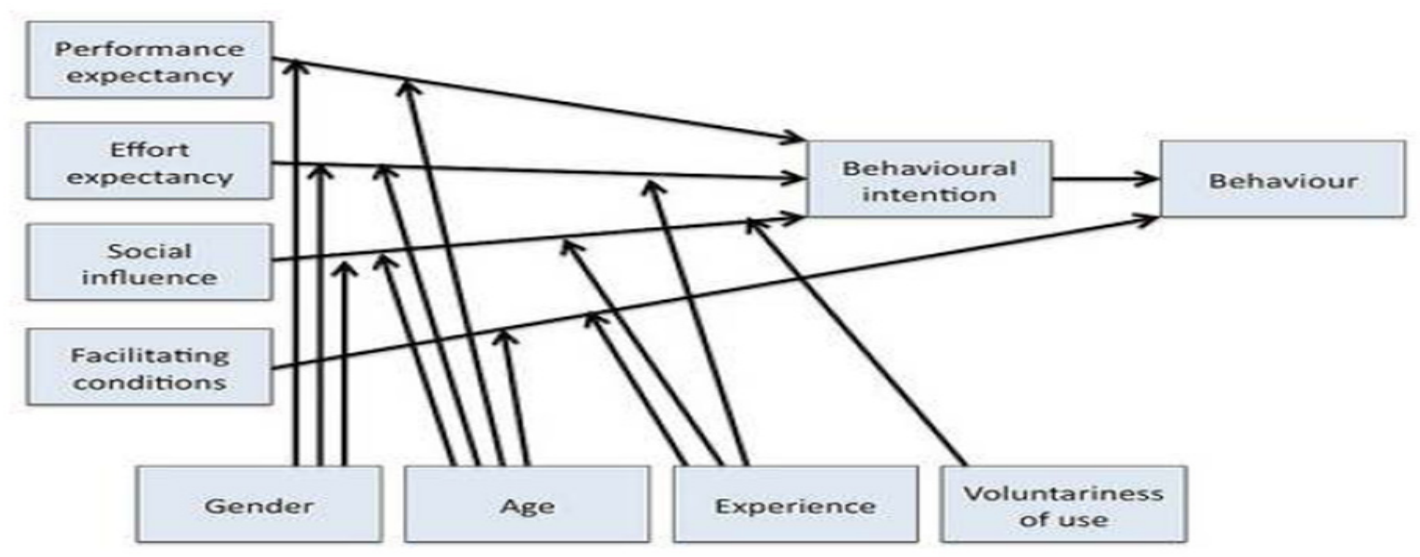

Picture 1. Unified Theory of Acceptance and Usage of Technology (UTAUT) model. 
Table 1. Factors related to Behavior of Use

\begin{tabular}{|c|c|c|c|c|c|c|}
\hline Model 1 & Coefficient & $95 \% \mathrm{CI}$ & & $p$ value & $\mathrm{R}$ & $\mathrm{R} 2$ \\
\hline (Constant) & 5.514 & $-.858-$ & 11.887 & .088 & 0,538 & 0,290 \\
\hline Behavioral intentions & .466 & $.181-$ & .751 & .002 & & \\
\hline Sigizi facility condition & .067 & $-.125-$ & .258 & .486 & & \\
\hline Respondent Age & -.115 & $-.248-$ & .018 & .088 & & \\
\hline $\begin{array}{l}\text { Working experience on } \\
\text { Health Centre }\end{array}$ & .124 & $-.011-$ & .259 & .071 & & \\
\hline Model 2 & Coefficient & $95 \% \mathrm{CI}$ & & $\mathrm{p}$ value & $\mathrm{R}$ & $\mathrm{R} 2$ \\
\hline (Constant) & 2.770 & -2.469 & 8.008 & .293 & 0,486 & 0,236 \\
\hline Behavioral intentions & .452 & .166 & .737 & .003 & & \\
\hline Sigizi facility condition & .084 & -.109 & .277 & .387 & & \\
\hline
\end{tabular}

Source : Primary Data

D3 (74\%); the majority of respondents were puskesmas nutrition officers (44\%); the majority of experiences using the Nutrition Information System range from 1-5 years (42\%); the majority use daily Nutrition Information System <2 hours (60\%).

The results of the UTAUT Variable Correlation and Regression Analysis are listed in Table 1.

Based on the results of hypothesis testing behavioral intention variable is $\mathrm{p}=0.002$ ( $\alpha$ $<0.05$ ), it is said to be statistically significant / significant, with a confidence level (CI) of $95 \%$, the difference between 0.181 to 0.751 . The correlation analysis results show that there is a relationship between behavioral intention with the use behavior $(\mathrm{R}=0.538)$. Sugiyono (2008) states that the $\mathrm{R}$ value of 0.40 to 0.599 indicates that there is a fair / moderate relationship, namely between behavioral intention and use behavior.

The results of the analysis of determination obtained the value of $\mathrm{R} 2$ ( $\mathrm{R}$ Square) of 0.236 or $(23.6 \%)$. This shows that the percentage contribution of the influence of the independent variable behavior intention on the dependent variable use behavior is $23.6 \%$. Or variations in the independent variables used in the model can explain $23.6 \%$ of the variation of the dependent variable. While the remaining $76.4 \%$ is influenced or explained by other variables.

The straight line equation that we get is: $\mathrm{Y}=5,514+(0,466) \mathrm{X} 1+(0,067) \mathrm{X} 2$
Where:

$\mathrm{Y}=$ use behaviour

$\mathrm{X} 1=$ behavioural intention

$\mathrm{X} 2=$ facilitating condition

A constant of 5.514 states that if behavioral intention and facility conditions, is 0 then the use behavior is 5.514. The regression coefficient of $\mathrm{X} 1$ variable is 0.466 , meaning that if the independent variable is fixed, then every increase of $1 \%$ of behavioral intention will increase the use behavior of 0.466 . X2 regression coefficient of 0.067 means that if another independent variable has a fixed value then every $1 \%$ increase in facility conditions will increase the use behavior by 0.067 .

Referring to the test results, it is known that the factor associated with the use behavior is behavioral intention. Intention will affect a person's attitude. Attitude is a reaction or response that is still closed from someone to a stimulus or object. Attitude is a person's feelings, thoughts and tendencies which are more or less permanent regarding certain aspects of their environment. Attitude is an evaluative bias towards a stimulus or object that has an impact on how someone is dealing with that object. According to Fishbein in Mulyati, et al. (2015) attitude is affective responses or judgments of someone's positivity towards an object. Attitude originates from beliefs about behavior (behavioral beliefs) and one's evaluation of the consequences to be borne (Montano, 2008 in Mulyati, 2015). While the facility condition 
factor (facilitating condition) Nutrition Information System is not related to the use behavior, even though the effect of respondent age and work experience have been controlled. However, the test results also show that the age of the respondent and the experience of working in the health center affect the relation of the condition of the nutritional information system facility to the behavior of use.

UTAUT explains behavioral intentions to use or adopt information technology by proposing four predictive factors (Venkatesh et al., 2003): performance expectancy, effort expectancy, social influence, and facilitation conditions. Venkatesh et al., (2003) identified four key moderators believed to influence the relation between major determinants and intentions: gender, age, voluntariness, and experience.

Nematollahi et al., (2017) results showed that there is a direct positive relation between Effort Expectancy and Behavioral Intention ( $p$ $=0.01)$ as well as between facility conditions and behavioral intention $(\mathrm{p}=0.04)$ and between facility conditions and Use behavior $(\mathrm{p}=0.01)$. In addition, there is a direct and positive relation between behavioral intention and use behavior. To improve the Electronic Medical Records use behavior in hospitals it is recommended that managers and policy makers consider increasing behavioral intentions and information system facility conditions.

Lian and Yen (2014) state that older information system users tend to see high risks in adopting technology and information technology capabilities for older users are generally lower than younger users. In addition, older users tend to have a tradition / habit barrier that is relatively higher than the younger generation because older users generally know manual / conventional services rather than virtual services. Based on these findings, this research concluded that the obstacles experienced by older users causes a decrease in the interest of parents to use information systems. Older information system users want a system that is easy to use and ergonomic. Those who have experienced using health information systems will be more adaptable to various forms of information systems used, whether information systems with modern conditions or simple facilities.

Table 2. Factors related to behavioral intentions

\begin{tabular}{|c|c|c|c|c|c|c|}
\hline Model 1 & Coefficient & $95 \% \mathrm{CI}$ & & $\mathrm{p}$ value & $\mathrm{R}$ & $\mathrm{R}^{2}$ \\
\hline (Constant) & 7.735 & 2.052 & 13.417 & .009 & 0,7 & 0,491 \\
\hline $\begin{array}{l}\text { Expected } \\
\text { Performance }\end{array}$ & .381 & .235 & .527 & .000 & & \\
\hline Sigizi user friendliness & .196 & .025 & .367 & .026 & & \\
\hline Social influence & -.119 & -.289 & .051 & .166 & & \\
\hline Sex_recode & -.365 & -2.663 & 1.934 & .751 & & \\
\hline Respondent age & -.017 & -.135 & .100 & .769 & & \\
\hline $\begin{array}{l}\text { Working experience on } \\
\text { Health Centre }\end{array}$ & .002 & -.113 & .117 & .972 & & \\
\hline Sigizi using experience & -.101 & -.393 & .191 & .488 & & \\
\hline Model 2 & Coefficient & $95 \% \mathrm{CI}$ & & $\mathrm{p}$ value & $\mathrm{R}$ & $\mathrm{R}^{2}$ \\
\hline (Constant) & 7.701 & 2.939 & 12.463 & .002 & 0,696 & 0,484 \\
\hline $\begin{array}{l}\text { Expected Sigizi } \\
\text { Performance }\end{array}$ & .374 & .234 & .515 & .000 & & \\
\hline Sigizi user friendliness & .199 & .034 & .364 & .019 & & \\
\hline Social influence & -.110 & -.270 & .050 & .174 & & \\
\hline Respondent age & -.025 & -.064 & .013 & .185 & & \\
\hline
\end{tabular}

Source: Primary Data 
From the results of the hypothesis test can be seen that the expected performance variable (performance expectancy) is $\mathrm{p}=0,000$ $(\alpha<0.05)$, so it is statistically significant, with a confidence level (CI) of $95 \%$, the difference between 0.235 to 0.527 . So based on the effort expectancy variable $p=0.026(\alpha<0.05)$, it is said to be statistically significant, with a confidence level (CI) of 95\%, the difference between 0.25 to 0.367 . The results of correlation analysis show that there is a relation between expected performance (performance expectancy), expected convenience (effort expectancy), and social influence with behavioral intention $(\mathrm{R}=$ 0.7 ). Sugiyono (2008) states that the $R$ value of 0.60 to 0.799 shows that there is a strong relation between expected performance (performance expectancy), expected convenience (effory expectancy) with social influence and behavioral intention.

Meanwhile, the determination analysis obtained R2 (R Square) value of 0.491 or (49.1\%). This shows that the percentage of the contribution of the expected performance (performance expectancy) independent variable, expected convenience (effort expectancy), and social influence to the behavioral intention dependent variable is $49.1 \%$. Or variations in the independent variables used in the model can explain $49.1 \%$ of the variation of the dependent variable. While the remaining $50.9 \%$ is influenced or explained by other variables.

The straight line equation we get is:

$\mathrm{Y}=7,735+(0,381) \mathrm{X} 1+(0,196) \mathrm{X} 2+(-0,119) \mathrm{X} 3$

Where:

$\mathrm{Y}=$ behavioural intention

$\mathrm{X} 1=$ performa expectancy

$\mathrm{X} 2=$ effort expectancy

$\mathrm{X} 3=$ social influence

A constant of 7.735 states that if the expected performance (performance expectancy), expected convenience (effort expectancy), and social influence are 0 then the behavioral intention is 7.735. The regression coefficient of X1 variable is 0.381 meaning that if the independent variable is fixed, then every $1 \%$ increase in expected performance (performance expectancy) will increase behavioral intention 0.381 . Regression X2 coefficient of 0.196 means that if the other independent variables are fixed, then every $1 \%$ increase in expected effort will increase behavioral intention by 0.196 . X3 regression coefficient of -0.119 means that if the other independent variables are fixed then each increase $1 \%$ of social influence will decrease behavioral intention by 0.119 .

Based on the test results it is known that the factors associated with behavioral intention are the expected performance of nutritional information systems (performance expectancy), the easiness of nutritional information systems (effort expectancy) and social influence. Meanwhile the age factor of the respondent is a confounding variable for effort expectancy and social influence to behavioral intentions.

The results of this research prove that there is a relation between expected performance (performance expectancy), and behavioral intention with the use of information systems. The higher the expected performance (performance expectancy), the higher the behavioral intention of someone to use information systems. This is in accordance with the theory put forward by Venkatesh (2003) that the expected performance (performance expectancy) is closely related to behavioral intentions to use information systems (Hartono, 2008; Handayani, 2007).

Social influence (social influence) which is higher will increase a person's behavioral intention to use information systems, and vice versa. The results of this study are in accordance with the UTAUT theory which explains that social influence factors are closely related to a person's behavioral intentions to use information systems (Hartono, 2008; Sedana and Wijaya, 2010). The results also show that the effort expectancy will increase someone's behavioral intention to use information systems, and vice versa. User friendliness that must exist in health information systems: First, health information technology must be easy to use, by simplifying the task of learning and mastering the system, making it easier to remember how to do system tasks, and increasing flexibility in using. Second, the function of health services technology must be uncomplicated and flexible according to requirement, the system to 
respond and search, the system is not difficult to use, information and data can be managed clearly and systematically by health staff (Phichitchaisopa and Naenna, 2013).

The facility conditions does not have a positive effect on usage behavior. This is not in accordance with previous results of the study (Kijsanayotin et al., 2009; Zhou et al., 2010; Rouibah et al., 2009). This implies that infrastructure support, such as a computer system is not the most important. Information technology devices are complementary, which is primarily behavioral intention. Modern or simple nutritional information systems that are available, will still be operated by the user because of the strong behavioral intention. Not enough infrastructure, another important condition that facilitates the adoption of health information systems by health workers is policy (Menachemi et al., 2011). There is infrastructure without its adoption policy that is less than optimal, for example, made a standard operating procedure for implementing health information systems, internal organizations provide technical support to use health information systems, such as information technology staff as technology support assistants for health care workers.

\section{Conclussion}

Based on the analysis of the influence of behavioral intention percentage contribution on the use behavior variable of $23.6 \%$; the influence of expected performance variables percentage (performance expectancy), expected convenience (effort expectancy), and social influence (social influence) on the behavioral intention dependent variable is $49.1 \%$. Therefore, the adoption of a health information system needs to consider behavioral intention, performance expectancy, effort expectancy, and social influence.

\section{Acknowledgement}

The author would like to thank the General Soedirman University Research and Community Service Institute for funding this research, the Health Centre and the Banyumas District Health Office who were willing to cooperate in this research.

\section{References}

Aggelidis, VP and Chatzoglou, PD. 2009. Using a Modified Technology Acceptance Model in
Hospitals. International Journal of Medical Informatics, Volume 78, Issue 2 : 115-126. Dilihat 1 Desember 2017. < https://www. ncbi.nlm.nih.gov/pubmed/>

Bashshur RL, Shannon GW, Krupinski EA, Grigsby J, Kvedar JC, Weinstein RS, Sanders JH, Rheuban KS, Nesbitt TS, Alverson DC, Merrell RC, Linkous JD, Ferguson AS, Waters RJ, Stachura ME, Ellis DG, Antoniotti NM, Johnston B, Doarn CR, Yellowlees P, Normandin S, Tracy J. 2009. National Telemedicine Initiatives: Essential to Healthcare Reform. Telemed J E- Health, Jul-Aug; 15 (6) : 600-10. Dilihat 1 Desember 2017. <https://www.ncbi.nlm.nih.gov/ pubmed>

Blumenthal D, and Glaser JP. 2007. Information Technology Comes to Medicine. N Engl J Med, June 14;356 (24) : 2527-34. Dilihat 1 Desember 2017.< http://www.nejm.org/doi/ full>

Boonstra A, and Broekhuis M. 2010. Barriers to The Acceptance of Electronic Medical Records by Physicians from Systematic Review to Taxonomy and Interventions. BMC Health Services Research, 10:231. Dilihat 1 Desember 2017. <http://www. biomedcentral.com>

Chaudhry B, Wang J, Wu S, Maglione M, Mojica W, Roth E, Sally CM, Paul GS, 2006. Systematic Review: Impact of Health Information Technology on Quality, Efficiency, and Costs of Medical Care. Ann Intern Med, 144(10): 742-752. Dilihat 1 Desember 2017. < http:// annals.org/aim/fullarticle>

Chien CL, Shih PL, Shu LY, Mei YT, Kuang YC. 2013. Evaluating the Influence of Perceived Organizational Learning Capability on User Acceptance of Information Technology Among Operating Room Nurse Staff. Acta Anaesthesiologica Taiwanica, 51 issue 1: 22-27 Dilihat 1 Desember 2017< http:// linkinghub.elsevier.com/retrieve/>

Davidson E, Heslinga D. 2007. Bridging The IT Adoption Gap for Small Physician Practices: An Action Research Study on Electronic Health Records. Information Systems Management, Volume 24 Issue 1 : 15-28. Dilihat 1 Desember 2017.< https://dl.acm. org/citation>

Eysenbach G. 2001. What is E-Health? J Med Internet Res, Apr-Jun; 3 (2): 20. Dilihat 1 Desember 2017. < https://www.ncbi.nlm. nih.gov/pmc/articles>

Gagnon MP, Desmartis M, Labrecque M, Car J, Pagliari C, Pluye P, Frémont P, Gagnon J, 
Tremblay N, and Légaré F. 2012. Systematic Review of Factors Influencing The Adoption of Information and Communication Technologies by Healthcare Professionals. J Med Syst, Feb; 36(1) : 241-277. Dilihat 1 Desember $2017<$ https://www.ncbi.nlm.nih. gov/pmc/articles/>

Gagnon MP, Breton E, Paré G, Courcy F, Côté J, Trépanier A, Fortin JP, Rouillon F. 2013. L'influence des Technologies de l'Information et des Communications sur le Maintien en Poste des Infirmières [The influence of information and communication technologies on nurses' retention] Sante Publique, May-Jun; 25(3) : 305-13. Dilihat 1 Desember 2017. < https://www.ncbi.nlm. nih.gov/pubmed/>

Handayani R. 2007. Analisis Faktor-Faktor Yang Mempengaruhi Niat Pemanfaatan Sistem InformasiDan Penggunaan Sistem Informasi (Studi Empiris Pada Perusahaan Manufaktur di Bursa Efek Jakarta). Jurnal Akuntansi dan Keuangan, Vol 9, No 2. Dilihat 1 Desember 2017. <http://jurnalakuntansi.petra.ac.id>

Hartono, Jogiyanto. 2008. Sistem Informasi Keperilakuan. Yogyakarta. Andi Offset

Holden RJ, Karsh BT. 2010. The Technology Acceptance Model: Its Past and Its Future in Health Care. J Biomed Inform, Feb; 43 (1): 159-72. Dilihat 1 Desember 2017. < https:// www.ncbi.nlm.nih.gov/pmc/articles/>

Jha AK, DesRoches CM, Campbell EG, Donelan K, Rao SR, Ferris TG, Shields A, Rosenbaum S, Blumenthal D.2009. Use of Electronic Health Records in U.S. Hospitals. N Engl J Med, Apr 16;360 (16):1628-38. Dilihat 1 Desember 2017. < https://www.ncbi.nlm.nih.gov/ pubmed/>

Kemenkes RI, 2013. Petunjuk Penggunaan Aplikasi Sistem Informasi Gizi Capaian Indikator Pembinaan Gizi. Direktorat Bina Gizi Masyarakat. Jakarta. Dilihat 1 Desember 2017. < http://gizi.depkes.go.id/sigizi>

Kijsanayotin B, Pannarunothai S, Speedie SM. 2009. Factors Influencing Health Information Technology Adoption in Thailand's Community Health Centers: Applying The UTAUT Model. Int J Med Inf; Jun; 78 (6) : 404-16. Dilihat 1 Desember 2017. < https:// www.ncbi.nlm.nih.gov/pubmed>

Lian JW, and Yen DC. 2014. Online Shopping Drivers and Barriers for Older Adults: Age and Gender Differences. Computers in Human Behavior, 37:133-143. Dilihat 1 Desember 2017. < www.elsevier.com/locate/ comphumbeh>
Lluch M. 2011. Healthcare Professionals' Organisational Barriers to Health Information Technologies-a Literature Review. Int J Med Inform, Dec;80(12) : 84962. Dilihat 1 Desember 2017. < https://www. ncbi.nlm.nih.gov/pubmed/>

Liu SH, Liao HL, Peng CJ. 2005. Applying The Technology Acceptance Model and Flow Theory to Online e-Learning Users' Acceptance Behavior. Elearn, Volume VI, No. 2. Dilihat 1 Desember 2017. <.http:// wwwiacis.org/iis/>

Menachemi N, Shin DY, Ford EW, Yu F. 2011. Environmental Factors and Health Information Technology Management Strategy. Health Care Manage Rev, JulSep;36(3): 75-85. Dilihat 1 Desember 2017. < http://insights.ovid.com/pubmed>

Mulyati S, Suwarsa O, Arya IFD. 2015. Pengaruh Media Film terhadap Sikap Ibu pada Deteksi Dini Kanker Serviks. Jurnal Kesehatan Masyarakat KEMAS, 11 (1) : 16-24 Dilihat 26 Mei $2018<$ http://journal.unnes.ac.id/nju/ index.php/kemas $>$

Nematollahi M, Moosavi A, Lazem M, Aslani N, Kafashi M, Ali, G. 2017. Factors Affecting in Adoption and Use of Electronic Medical Record Based on Unified Theory of Acceptance and Use of Technology in Iran. Shiraz E-Med J, September 18(9). Dilihat 1 Desember 2017.< http://emedicalj.com/en/ articles>

Oshlyansky L, Cairns P, Thimbleby H. 2007. "Validating the Unified Theory of Acceptance and Use of Technology (UTAUT) Tool CrossCulturally," in 21st British HCI Group Annual Conference on People and Computers, Volume 2. pp. 83-86. Dilihat 1 Desember 2017 < https://dl.acm.org/citation>

Phichitchaisopa N, and Naenna T. 2013. Factor Affecting The Adoption of Healthcare Information Technology. EXCLI Journal, 12 : 413-436. Dilihat 1 Desember 2017.<https:// www.ncbi.nlm.nih.gov/pmc/articles/>

Rouibah K, Hamdy HI, Al-Enezi MZ. 2009. Effect of Management Support, Training, and User Involvement on System Usage and Satisfaction in Kuwait. Ind Manage Data Sys, 103, No $9: 338-356$. Dilihat 1 Desember 2017.<http://citeseerx.ist.psu.edu>

Schaupp LCL, Carter, Mcbride, ME. 2010. "E-File Adoption: A Study of U.S. Taxpayers' Intentions," Comput. Human Behav, vol. 26, no. 4 : 636-644. Dilihat 1 Desember 2017. << www.elsevier.com/locate/>.

Sedana I, Wijaya W. 2010 . UTAUT Model for 
Understanding Learning Management System. Internetworking Indonesia Journal, Vol.2, No.2. Dilihat 1 Desember 2017. < www.internetworkingindonesia.org $>$.

Sugiyono, 2008. Metode Penelitian Bisnis, Pendekatan Kuantitatif, Kualitatif, dan R\&D. Cetakan Kedua Belas. Bandung: CV. Alfabeta.

Venkatesh V, Morris MG, Davis GB, Davis FD. 2003. User Acceptance of Information Technology: Toward a Unified View. MIS Quarterly, Vol. 27 No. 3. Dilihat 1 Desember 2017. < www. vvenkatesh.com>
While A, Dewsbury G. 2011. Nursing and Information and Communication Technology (ICT): a Discussion of Trends and Future Directions. International Journal of Nursing Studies, vol 48, no. 10 : 1302-1310. Dilihat 1 Desember 2017.< https://kclpure. kcl.ac.uk/>

Zhou T, Lu Y, Wang B. 2010. Integrating TTF and UTAUT to Explain Mobile Banking User Adoption. Comput Hum Behav, 26 : 760767. Dilihat 1 Desember 2017.< www.scirp. org> 